\title{
Postoperative analgesia for arthroscopic rotator cuff surgery: a comparison between subacromial and interscalene levobupivacaine
}

\author{
Artroskopik rotator kaf cerrahisi için postoperatif analjezi: \\ Subakromiyal ve interskalen levobupivakainin karşılaştırılması
}

\author{
Kemalettin KOLTKA,' Behiye DOĞRUEL,' Mert ŞENTÜRK,' Ata Can ATALAR,'2 \\ Süleyman KÜÇÜKAY,' Kamil PEMBECi'
}

\begin{abstract}
Summary
Objectives: Arthroscopic rotator cuff surgery can result in severe postoperative pain. We compared a continuous subacromial infusion to a continuous interscalene block with levobupivacaine for patients undergoing arthroscopic rotator cuff surgery.

Methods: Sixty patients were randomized to two groups: 1$)$ interscalene block with $0.5 \%$ levobupivacaine ( $30 \mathrm{~mL})$ followed by a postoperative subacromial infusion: $0.125 \%$ levobupivacaine $5 \mathrm{~mL} / \mathrm{h}$ basal infusion, $5 \mathrm{~mL}$ bolus dose and a 20 min lockout time or; 2 ) interscalene block with $0.5 \%$ levobupivacaine $(30 \mathrm{~mL})$ followed by a postoperative interscalene infusion: $0.125 \%$ levobupivacaine $5 \mathrm{~mL} / \mathrm{h}$ basal infusion, $5 \mathrm{~mL}$ bolus dose and a 20 min lockout time. Infusions were maintained for 48 hours. Results: The VAS scores in the postanesthesia care unit and at $4 \mathrm{~h}$ were not different. The VAS scores at 8, 12, 24, 36 and 48 $\mathrm{h}$ were lower than 4 in both groups; but they were significantly lower in the interscalene group. Additional analgesic requirements were lower in the interscalene group $(16.6 \%$ vs $53.3 \%, \mathrm{p}<0.05)$. Patients' satisfaction was higher in the interscalene group $(9.4 \pm 0.8$ vs $8 \pm 1.2, \mathrm{p}<0.01)$. One patient had a toxicity related to interscalene block but; there was no complication related to subacromial catheters.

Conclusion: This study demonstrates that subacromial infusions, although provided good postoperative analgesia, are not as effective as interscalene infusions and additional analgesics should be prescribed when subacromial infusions are started. Subacromial infusions could be considered as an alternative in case of any contraindication to interscalene block.
\end{abstract}

Key words: Arthroscopic rotator cuff surgery; interscalene catheter; levobupivacaine; subacromial catheter.

\section{Özet}

Amaç: Artroskopik rotator kaf cerrabisi şiddetli ăgrıya neden olabilir. Çalı̧̧mamızda, artroskopik rotator kaf cerrabisi hastalarında subakromiyal kateterden devaml uygulanan levobupivakain infüzyonu ile interskalen kateterden devaml uygulanan levobupivakain infüzyonunu karşılaştırdık.

Gereç ve Yöntem: Altmış hasta iki gruba randomize olarak ayrıldı: 1) $30 \mathrm{ml} \% 0.5^{\prime}$ lik levobupivakain ile tek doz interskalen blok sonrasinda subakromial kateterden \%0.125'lik levobupivakain $5 \mathrm{ml} / \mathrm{s}$ bazal infüzyon, $5 \mathrm{ml}$ bolus doz ve kilitli kalma 20 dakika; 2) $30 \mathrm{ml} \% 0.5$ 'lik levobupivakain ile interskalen blok sonrasinda interskalen kateterden \%0.125'lik levobupivakain $5 \mathrm{ml} / \mathrm{s}$ bazal infüzyon, $5 \mathrm{ml}$ bolus doz ve kilitli kalma 20 dakika. İnfüzyonlara 48 saat süre devam edildi.

Bulgular: Derlenme odasındaki ve 4 saat sonraki VAS değerleri açısından gruplar arasında fark yoktu. Çalışmamızda 8, 12, 24, 36 ve 48. saatlerde VAS değerleri iki grupta da medyan değer olarak 4'ten küçük olmakla beraber interskalen grupta istatistiksel olarak anlamlı derecede daba düşüktü. Ek analjezik gereksinimi interskalen grupta istatistiksel olarak anlamlı derecede daha azdı (\%16.6 ve \%53.3, $p<0.05)$. Hasta memnuniyeti interskalen grupta istatistiksel olarak anlamli derecede daba yüksekti $(9.4 \pm 0.8$ ve $8 \pm 1.2, p<0.01)$. Inters kalen blok uygulamasına bağ̆l bir olguda toksisite gelişirken subakromiyal kateter uygulamasına bağglı biç bir komplikasyon gelişmedi. Sonuç: Artroskopik rotator kaf cerrabisi operasyonlarından sonra subakromiyal kateterden lokal anestetik uygulamast yeterli bir ağr kontrolü sağlasa bile interskalen kateterden devamlı lokal anestetik uygulaması kadar başarılı olamamıştır. Subakromiyal kateter uygulanacaksa bu hastalara mutlaka ek analjezik tedavi protokolü de düzenlenmelidir. Ancak, interskalen blok için bir kontrendikasyon varlı̆̆inda subakromiyal kateter alternatif bir tedavi yöntemi olarak akılda tutulmalıdır.

Anahtar sözcükler: Artroskopik rotator kaf cerrahisi; interskalen kateter; levobupivakain; subakromiyal kateter.

Departments of ${ }^{1}$ Anesthesiology, ${ }^{2}$ Orthopedics and Traumatology, Istanbul University, Istanbul Faculty of Medicine, Istanbul, Turkey Istanbul Üniversitesi Istanbul Tıp Fakültesi, 'Anesteziyoloji Anabilim Dalı, ${ }^{2}$ Ortopedi ve Travmatoloji Anabilim Dalı, istanbul 


\section{Introduction}

Arthroscopic rotator cuff surgery is often associated with severe postoperative pain especially in the first 48 hours. This not only causes patient discomfort but also compromises the intensive postoperative rehabilitation necessary for a good functional result. Continuous interscalene block is accepted as the gold standard after major shoulder surgery but there are also some alternative methods including intramuscular injection of analgesics, intraarticular injection of morphine and bupivacaine, ${ }^{[1,2]}$ patient-controlled analgesia (PCA) using intravenous injection, ${ }^{[3]}$ and continuous-flow cold therapy. ${ }^{[4]}$ Patient-controlled analgesia after shoulder surgery, specifically, patientcontrolled intravenous injection after open surgery ${ }^{[5]}$ and patient-controlled subacromial infusion after arthroscopic surgery, has become more common. ${ }^{[6,7]}$ The efficacy of patient-controlled subacromial infusion after arthroscopic shoulder surgery has been confirmed by many authors, ${ }^{[6-8]}$ and subacromial ropivacaine was compared with interscalane ropivacaine ${ }^{[9]}$ but no study has compared pain control results of subacromial and interscalene levobupivacaine.

The aim of this prospective, randomized study was to compare the requirement of additional analgesics, the effectiveness, patient satisfaction, and complications of subacromial infusion and interscalene infusion of levobupivacaine after arthroscopic rotator cuff surgery.

\section{Materials and Methods}

Patients scheduled for arthroscopic rotator cuff surgery classified as ASA physical status I-III, aged 18 yr or older, participated in this study. All patients gave written informed consent for the study, which was approved by the local research ethics committee. Patient exclusion criteria included chronic opioid use, morbid obesity or contraindications to regional anesthesia.

After an 18-gauge intravenous (IV) cannula was inserted in the forearm, midazolam $0.05 \mathrm{mg} / \mathrm{kg} \mathrm{IV}$ was given as premedication, and standard monitors were placed, including noninvasive arterial blood pressure, heart rate, and pulse oximetry. After local skin infiltration with $20 \mathrm{mg}$ of $2 \%$ lidocaine all patients received an interscalene brachial plexus block with $30 \mathrm{~mL} 0.5 \%$ levobupivacaine preoperatively. Patients were then randomized using a computer generated sequence of numbers to one of two groups: 1) subacromial catheter group ( $\mathrm{SAC} ; \mathrm{n}=30)$ : postoperative continuous subacromial infusion; 2) interscalene group (ISC; $n=30$ ): postoperative continuous interscalene infusion.

Using the approach previously described by Mei$\mathrm{er}^{[10]}$ single injection blocks were placed using a 50$\mathrm{mm}$ insulated, blunt needle and a nerve stimulator. After finding a distal motor response at $<0.5 \mathrm{~mA}$, $30 \mathrm{~mL}$ of $0.5 \%$ levobupivacaine was injected to all patients. The SAC group had the epidural catheters inserted through the anterior portal and located in the subacromial space at the end of the operation by the surgeon. The ISC group had their blocks placed using the same technique but with the Contiplex D System $^{\oplus}$ (B. Braun Medical, Melsungen AG, Melsungen, Germany). The ISC group also had a catheter inserted through the introducer needle for 4-5 $\mathrm{cm}$ into the plexus sheath and secured to the skin. After negative aspiration of the catheter, a $3 \mathrm{~mL}$ test dose was given and than a total of $30 \mathrm{~mL}$ of $0.5 \%$ levobupivacaine was injected.

General anesthesia was induced in all patients with $1-2 \mu \mathrm{g} / \mathrm{kg}$ fentanyl, $2-2.5 \mathrm{mg} / \mathrm{kg}$ propofol, and 0.5 $\mathrm{mg} / \mathrm{kg}$ atracurium IV. The trachea was intubated, and controlled ventilation was started. Anesthesia was maintained with a mixture of nitrous oxide $(60 \%)$ and sevoflurane $1-3 \%$ in oxygen.

In the recovery room, the correct position of the interscalene catheter was confirmed by a sensory block (reduced or loss of temperature sense assessed by using an ether-soaked swab) involving at least one major nerve distribution (axillary, musculocutaneous, median, or radial) of the arm. Patient controlled analgesia was started $4 \mathrm{~h}$ after the initial interscalene block and continued during the first $24 \mathrm{~h}$ postoperatively, Group SAC received, through the subacromial catheter, a continuous infusion of $0.125 \%$ levobupivacaine $5 \mathrm{~mL} / \mathrm{h}$, a bolus of $0.125 \%$ levobupivacaine $5 \mathrm{~mL}$ with a 20 minutes lockout time. Group ISC received, through the interscalene catheter, a continuous infusion of $0.125 \%$ levobupivacaine $5 \mathrm{~mL} / \mathrm{h}$, a bolus of levobupivacaine $0.125 \% 5$ $\mathrm{mL}$ with a 20 minutes lockout time. 
Pain intensity was assessed with a $10 \mathrm{~cm}$ visual analog scale (VAS) $(0 \mathrm{~cm}=$ no pain; $10 \mathrm{~cm}=$ worst possible pain) while asking the patients to move the hand and flex the elbow joint.

If pain was not adequately controlled (pain score $>3$ on the visual analog scale [VAS; ranging from $0=$ no pain to $10=$ worst pain imaginable]), patients received $20 \mathrm{mg}$ of iv tenoxicam followed by $0.5 \mathrm{mg} /$ $\mathrm{kg}$ of IV pethidine, if pain remained unchanged after 30 minutes.

The degree of pain was recorded at the immediate postoperative period (0 hour) and then at 4, 8, 12, 24,36 , and $48 \mathrm{~h}$ after surgery. Total consumption of local anesthetic solution, as well as the number of incremental doses asked and received by the patient, and the number of rescue tenoxicam and pethidine given during the first $48 \mathrm{~h}$ were recorded. At the end of the $48 \mathrm{~h}$ study period, the catheters were removed and patients were given oral analgesics, as routine in our institution. Patient's satisfaction was evaluated $48 \mathrm{~h}$ after surgery with a $10 \mathrm{~cm}$ scale $(0 \mathrm{~cm}=\mathrm{com}$ pletely dissatisfied; $10 \mathrm{~cm}=$ completely satisfied).

To detect a difference of $25 \%$ in the local anesthetic consumption accepting an $\alpha$ error of $5 \%$ and a $\beta$ error of $10 \%$, the required study size was 22 samples. Statistical analyses used an ordinary ANOVA test for intragroup differences with Dunn's post-hoc test when $p<0.05$ and Mann-Whitney $U$ test for intergroup differences. Differences in group demographic characteristics were tested by Student's t-test or contingency-table chi-square test for categorical measures. A p value $<0.05$ was considered significant.

\section{Results}

No differences in demographic variables as well as duration of surgical procedure were reported between the two groups (Table 1).

In the early postoperative period $(4 \mathrm{~h})$, mean VAS scores were comparable in the two groups: median VAS scores were 1 (range 0-4) in group SAC and 0 (range 0-4) in group ISC. At 8, 12, 24, 36 and 48 $\mathrm{h}$ postoperatively the median VAS values in both groups were lower than 4 in both groups, although
Table 1. Age, sex, ASA status and operation durations of groups (Mean \pm SD)

\begin{tabular}{lccc}
\hline & GSAC & GISC & p \\
\hline Age (Year) & $48.5 \pm 11.6$ & $43.9 \pm 11.9$ & NS \\
Sex (F/M) & $22 / 8$ & $21 / 9$ & NS \\
ASA Status (I/II) & $20 / 10$ & $22 / 8$ & NS \\
Operation duration (min) & $140 \pm 35$ & $135 \pm 31$ & NS \\
\hline
\end{tabular}

NS: Not significant.

they were significantly lower in Group ISC when compared with Group SAC ( $<<0.01, \mathrm{p}<0.01, \mathrm{p}<0.01$, $\mathrm{p}<0.0001, \mathrm{p}<0.001$ respectively) (Fig. 1).

The volume of local anesthetic solution administered to the patients at the end of $48 \mathrm{~h}$ PCA infusion were $386 \pm 86 \mathrm{ml}$ in group SAC and $255 \pm 63$ $\mathrm{ml}$ in group ISC $(\mathrm{p}<0.001$, Table 2$)$.

Rescue analgesics were given in 16 patients of the subacromial group $(53.3 \%)$ and 5 patients of the interscalene group (16.6\%) ( $\mathrm{p}=0.0211$, Table 2$)$. In 13 of the 16 patients of the subacromial group tenoxicam was adequate and only 3 patients required iv pethidine while 5 patients of the interscalene group required only iv tenoxicam.

Except one light local anesthetic toxicity no severe complications were reported in either group. This patient complained numbness of the tongue, dizziness, and tinnitus. Local anesthesia toxicity was considered and oxygen was applied via facemask and $2 \mathrm{mg}$ midazolam IV were given. The patient was followed in the recovery unit for one hour without any other symptoms of local anesthetic toxicity and

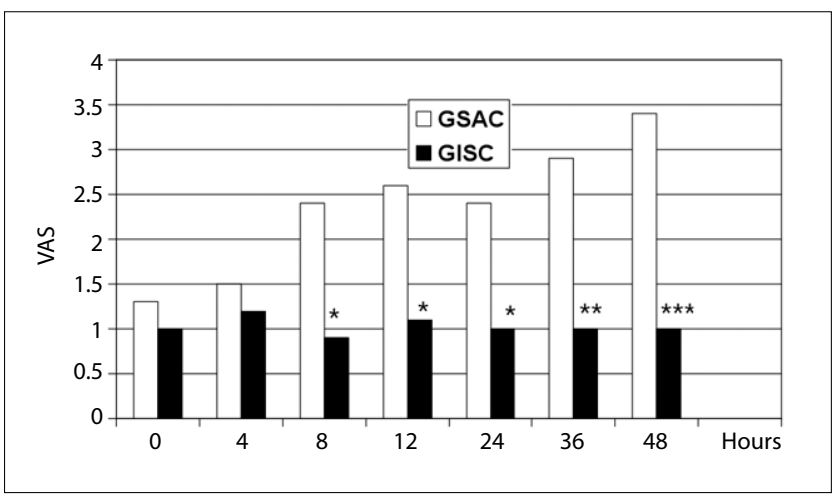

Fig. 1. VAS scores of the groups.

${ }^{*}: p<0.01 ;{ }^{* *}: p<0.001 ;{ }^{* * *}: p<0.0001$. 
Table 2. Volume of LA used, number of patients given rescue analgesic and patients' satisfaction of groups (Mean $\pm \mathrm{SD})$

\begin{tabular}{lccc}
\hline & GSAC & GISC & P \\
\hline Volume of LA used $(\mathrm{ml})$ & $386 \pm 86$ & $255 \pm 63$ & $\mathrm{p}<0.0001$ \\
Number of patients given rescue analgesic & $16(53.3 \%)$ & $5(16.6 \%)$ & $\mathrm{p}<0.05$ \\
Patients' satisfaction & $8 \pm 1.2$ & $9.4 \pm 0.8$ & $\mathrm{p}<0.01$ \\
\hline
\end{tabular}

was given to the operation under general anesthesia. Horner's syndrome (9/60, 15\% 5 patients in Group SAC vs 4 in Group ISC), hoarseness (3/60, 5\% 2 patients in Group SAC vs 1 in Group ISC) and respiratory distress $(5 / 60,8,33 \% 2$ patients in Group SAC vs 3 in Group ISC) were reported. All of the complications were reported after single shot or continuous interscalene block and were evenly distributed between the two groups: No complications were reported due to subacromial catheterization.

All of the patients have reported a satisfaction index of 6 and above, but the average satisfaction was significantly higher in the patients of the interscalene group (9.4 40.8 vs $8 \pm 1.2, \mathrm{p}<0.01$, Table 2$)$.

In our series the volume of local anesthetic solution administered to the patients at the end of at the end of $24 \mathrm{~h}$ PCA infusion was $220 \pm 52 \mathrm{ml}$ and it was $386 \pm 86 \mathrm{ml}$ after $48 \mathrm{~h}$ in group SAC. The volume of local anesthetic solution administered after $24 \mathrm{~h}$ PCA infusion was $145 \pm 38 \mathrm{~mL}$ and it was $255 \pm 63$ $\mathrm{ml}$ after $48 \mathrm{~h}$ PCA infusion in group ISC.

\section{Discussion}

Major shoulder surgery is often associated with severe postoperative pain, especially within the first 48 hours. ${ }^{[1]}$ This not only causes patient discomfort but also compromises the intensive postoperative rehabilitation necessary for a good functional result. Continuous interscalene brachial plexus block, single shot interscalene brachial plexus block, intravenous PCA, local injection of anesthetics and analgesics are commonly used techniques. All of these techniques have disadvantages, serious complications and adverse effects. On the other hand since Stein et al. ${ }^{[12]}$ reported effective pain alleviation after arthroscopic knee surgery with intra-articular infusion of a small amount of morphine, many authors have described pain control with the combined or isolated use of opioids and local anesthetics. ${ }^{[12,13]}$ Similar results have also been reported from arthroscopic shoulder surgery. ${ }^{[6,7]}$ Barber and Herbert $^{[4]}$ analyzed 50 patients who went through arthroscopic surgery for rotator cuff tears, superior labral anterior posterior lesions, and subacromial impingement syndrome and found that subacromial or intraarticular injection of $0.5 \%$ bupivacaine was effective. Harvey et al. ${ }^{[14]}$ reported similar results with the use of ropivacaine in 24 patients who underwent subacromial decompression.

In our series, on arrival to the PACU and in the early postoperative period $(4 \mathrm{~h})$ VAS scores were not significantly different between the group with subacromial infusion and the group with interscalene infusion. This is probably because of the ongoing effect of levobupivacaine $0.5 \%$ used for the interscalene block provides sufficient postoperative analgesia in the early postoperative period. For patient controlled interscalene analgesia (PCIA) different analgesia regiments were used: Borgeat et al. used $0.15 \%$ bupivacaine or $0.2 \%$ ropivacaine at a rate of $5 \mathrm{ml} \mathrm{h}^{-1}$ with a bolus dose of 3 or $4 \mathrm{ml}$ and a lockout time of $20 \mathrm{~min}^{[15,16]}$ while Sanfedo et al. used $0.1 \%$ ropivacaine at a rate of $5 \mathrm{ml} \mathrm{h}^{-1}$ with a bolus dose of $5 \mathrm{ml}$ and a lockout time of 20 min. ${ }^{[17]}$ These PCIA protocols are similar to our protocol and were effective and safe protocols. In the literature there is some controversy about the effectiveness of subacromial catheters after shoulder surgery, ${ }^{[8,14,18]}$ and different protocols and doses were used for pain control after shoulder surgery. For example Savoie et al. ${ }^{[8]}$ divided 62 patients who received subacromial decompression into 2 groups and infused $0.25 \%$ bupivacaine into the subacromial space in one group and normal saline in the other. They reported that the group with continuous infusion of bupivacaine showed better pain con- 
trol. Barber and Herbert ${ }^{[4]}$ found that subacromial or intraarticular injection of $0.5 \%$ bupivacaine was effective in various types of arthroscopic shoulder surgery. In contrast to the studies reporting beneficial effects of subacromial infusions, Quick et al. ${ }^{[18]}$ found no benefit over placebo with regard to pain, demand for rescue narcotic, or recovery of motion with subacromial bupivacaine infusion.

In our series the volume of local anesthetic solution administered after $48 \mathrm{~h}$ PCA infusion was $255 \pm 63$ $\mathrm{ml} .48 \mathrm{~h}^{-1}$ in group ISC. Casati et al. ${ }^{[19]}$ found the total consumption of local anesthetic infused during the first $24 \mathrm{~h} 147 \mathrm{~mL}(144-196 \mathrm{~mL})$ with levobupivacaine. When we reviewed our data for median value for group ISC we found that it was 140 $\mathrm{ml}$ which is similar to Casati's result. In a previous study ${ }^{[20]}$ we found the total consumption of bupivacaine $0.125 \%$ infused during the first $24 \mathrm{~h}$ in group ISC was $150 \pm 36 \mathrm{ml}$ and this is also similar to our findings with levobupivacaine.

In our series the volume of local anesthetic solution administered to the patients at the end of $48 \mathrm{~h}$ PCA infusion were $386 \pm 86 \mathrm{ml}$ in group $\mathrm{SAC}$ and this value is higher than the values in the literature. ${ }^{[20]}$ The reason of this discrepancy is probably the differences in PCA protocols: we used much higher local anaesthetic infusions than the other investigators.

In our series rescue analgesic medication requirement was significantly lower in the ISC group. Similar lower results have been reported by Borgeat et al. in studies comparing PCIA with iv PCA. ${ }^{[16,17]}$ For SAC, in studies comparing local anesthetic infusions with placebo lower additional analgesic requirements were found with local anesthetic infusions. ${ }^{[4,8]}$ In a previous study we found no statistically significant difference between the additional analgesic requirements of the ISC and SAC groups $(\mathrm{p}=0.06)$ but it was less in the ISC group. ${ }^{[20]}$

Although patient satisfaction was sufficiently high in both groups ( $\geq 6$ in all patients in both groups), it was higher in the ISC group like in several studies comparing PCIA with other PCA modalities. ${ }^{[15,16,20]}$ However, it has to be reported that the SAC strategy was also associated with a sufficient patient satisfaction, parallel to postoperative analgesia.
Interscalene block provides better postoperative analgesia than other postoperative analgesia techniques in shoulder surgery, but it can have serious side effects. In patients with chronic respiratory disease or in patients with contrlateral phrenic nerve paralysis performing an interscalene block may cause an ipsilateral phrenic paralysis which can lead to acute respiratory failure and is, therefore, contraindicated in these patients. ${ }^{[21-23]}$ In these cases, a safer alternative technique (subacromial infusion) other than an iv PCA with an opioid may be more suitable and in our series no complications were reported after subacromial catheterization.

The complication rates of our study were similar to that of the literature; for example Delaunay et al. ${ }^{[9]}$ had $10 \%$ of Horner's syndrome while we had $15 \%$ and Singely et al. ${ }^{[5]}$ had $16.6 \%$ incidence of Horner's syndrome. In the study done by Singelyn et al. hoarsness and phrenic paresis rates were found $16.6 \%$ and $16.6 \%$ while we found rates of $5 \%$ of hoarsness and $8.3 \%$ of respiratory distress.

A weakness of our study is that we do not have a long follow-up period of the patients. Do the ranges of motions of the patients in PCIA or subacromial PCA differ after 1, 2 or 6 months after surgery? We do not know the answers to this question.

\section{Conclusion}

Our conclusion is that continuous interscalene infusion of levobupivacaine is more efficient than contionous subacromial infusion of levobupivacaiene for pain control in arthroscopic rotator cuff surgery. If there is a contraindication to interscalene block a safer alternative like continuous subacromial infusion could be considered.

\section{References}

1. Boden BP, Fassler S, Cooper S, Marchetto PA, Moyer RA. Analgesic effect of intraarticular morphine, bupivacaine, and morphine/bupivacaine after arthroscopic knee surgery. Arthroscopy 1994;10(1):104-7.

2. Jaureguito JW, Wilcox JF, Cohn SJ, Thisted RA, Reider B. A comparison of intraarticular morphine and bupivacaine for pain control after outpatient knee arthroscopy. A prospective, randomized, double-blinded study. Am J Sports Med 1995;23(3):350-3.

3. Matheny JM, Hanks GA, Rung GW, Blanda JB, Kalenak A. A comparison of patient-controlled analgesia and continuous lumbar plexus block after anterior cruciate ligament recon- 
struction. Arthroscopy 1993;9(1):87-90.

4. Barber FA, Herbert MA. The effectiveness of an anesthetic continuous-infusion device on postoperative pain control. Arthroscopy 2002;18(1):76-81.

5. Singelyn FJ, Seguy S, Gouverneur JM. Interscalene brachial plexus analgesia after open shoulder surgery: continuous versus patient-controlled infusion. Anesth Analg 1999;89(5):1216-20.

6. Joshi GP, McCarroll SM. Intra-articular morphine for the management of frozen shoulder. Anaesthesia 1992;47(7):627.

7. Muittari PA, Nelimarkka O, Seppälä T, Kanto JH, Kirvelä OA. Comparison of the analgesic effects of intrabursal oxycodone and bupivacaine after acromioplasty. J Clin Anesth 1999;11(1):11-6.

8. Savoie FH, Field LD, Jenkins RN, Mallon WJ, Phelps RA 2nd. The pain control infusion pump for postoperative pain control in shoulder surgery. Arthroscopy 2000;16(4):339-42.

9. Delaunay L, Souron V, Lafosse L, Marret E, Toussaint B. Analgesia after arthroscopic rotator cuff repair: subacromial versus interscalene continuous infusion of ropivacaine. Reg Anesth Pain Med 2005;30(2):117-22.

10. Meier G, Bauereis C, Heinrich C. Interscalene brachial plexus catheter for anesthesia and postoperative pain therapy. Experience with a modified technique. Anaesthesist 1997;46(8):715-9. [Abstract]

11. Tuominen $\mathrm{M}$, Pitkänen $\mathrm{M}$, Rosenberg PH. Postoperative pain relief and bupivacaine plasma levels during continuous interscalene brachial plexus block. Acta Anaesthesiol Scand 1987;31(4):276-8.

12. Stein C, Comisel $K$, Haimerl E, Yassouridis A, Lehrberger $K$, Herz $A$, et al. Analgesic effect of intraarticular morphine after arthroscopic knee surgery. N Engl J Med 1991;325(16):11236.

13. Khoury GF, Chen AC, Garland DE, Stein C. Intraarticular morphine, bupivacaine, and morphine/bupivacaine for pain control after knee videoarthroscopy. Anesthesiology 1992;77(2):263-6.
14. Harvey GP, Chelly JE, AlSamsam T, Coupe K. Patient-controlled ropivacaine analgesia after arthroscopic subacromial decompression. Arthroscopy 2004;20(5):451-5.

15. Borgeat A, Schäppi B, Biasca N, Gerber C. Patient-controlled analgesia after major shoulder surgery: patient-controlled interscalene analgesia versus patient-controlled analgesia. Anesthesiology 1997;87(6):1343-7.

16. Borgeat A, Tewes E, Biasca N, Gerber C. Patient-controlled interscalene analgesia with ropivacaine after major shoulder surgery: PCIA vs PCA. Br J Anaesth 1998;81(4):603-5.

17. Sandefo I, Bernard JM, Elstraete V, Lebrun T, Polin B, Alla F, et al. Patient-controlled interscalene analgesia after shoulder surgery: catheter insertion by the posterior approach. Anesth Analg 2005;100(5):1496-8.

18. Quick DC, Guanche CA. Evaluation of an anesthetic pump for postoperative care after shoulder surgery. J Shoulder Elbow Surg 2003;12(6):618-21.

19. Casati A, Borghi B, Fanelli G, Montone N, Rotini R, Fraschini G, et al. Interscalene brachial plexus anesthesia and analgesia for open shoulder surgery: a randomized, double-blinded comparison between levobupivacaine and ropivacaine. Anesth Analg 2003;96(1):253-9.

20. Koltka K, Batmaz M, Atalar AC, Demirhan M, Kucukay S, Senturk $M$, et al. Comparison of different analgesia methods in shoulder surgery. JTAICS 2008;36(1):38-44.

21. Fujimura N, Namba H, Tsunoda K, Kawamata T, Taki K, Igarasi $M$, et al. Effect of hemidiaphragmatic paresis caused by interscalene brachial plexus block on breathing pattern, chest wall mechanics, and arterial blood gases. Anesth Analg 1995;81(5):962-6.

22. Gentili ME, Lefoulon-Gourves M, Mamelle JC, Bonnet F. Acute respiratory failure following interscalene block: complications of combined general and regional anesthesia. Reg Anesth 1994;19(4):292-3.

23. Kempen PM, O'Donnell J, Lawler R, Mantha V. Acute respiratory insufficiency during interscalene plexus block. Anesth Analg 2000;90(6):1415-6. 